\title{
Sense of coherence as a moderator of health- -related behavior of physical education teachers
}

\author{
Authors' Contribution: \\ A - Study Design \\ Zaneta Szczepanska-Klunder ${ }^{\text {ABCDEFG }}$, Mariusz Lipowski ${ }^{\text {ABDE }}$ \\ B - Data Collection \\ C - Statistical Analysis \\ D - Data Interpretation \\ Gdansk University of Physical Education and Sport in Gdansk, Poland
}

E - Manuscript Preparation

$\mathrm{F}$ - Literature Search

$\mathrm{G}$ - Funds Collection

Key words: health psychology, health behavior, health promotion, personality, physical activity.

Background:

Abstract

Material/Methods:

Sense of coherence is believed to be the main indicator of health-oriented behavior. Therefore, it is interesting to find out to what extent the sense of coherence moderates health behavior of physical education teachers. Materialmethods:
In order to address this issue, 477 physical education teachers were examined ( $n$ ㅇ $=$ 235; $\left.n{ }^{1}=242\right)$ aged 23-62 ( $M=40.05$; $\left.S D=9.09\right)$. Three methods were used in the research:Antonovsky's The Sense of Coherence Questionnaire (SOC-29), Health Behavior Inventory (HBI) by Juczynski and The Multidimensional Body-Self Relations Questionnaire by Cash.
Results: Results indicate a positive role of the sense of coherence in adopting Prophylactic Behavior, Positive Psychological Attitudes and Health Practices. However, they do not confirm its role with regard to physical activity. Regression analysis showed that comprehensibility ( $Q: \beta=0.20 ; p=0.008 ; 0: \beta=0.16 ; p=0.040$ ) and manageability $(O): \beta=0.27 ; p=0.001)$ are likely to result in Positive Psychological Attitudes; and Fitness/Health Evaluation influences Fitness/Health Orientation $(Q: \beta=0.55 ; p=$ $0.000 ; o^{\lambda}: \beta=0.43 ; p=0.000$ ).
Conclusions: The average indicator of subjects' health-seeking behavior indicates a need for inter- vention in terms of health promotion and education amongst $P E$ teachers. Changes in educating PE teachers may also be advisable.

Word count: 2,886

Tables: 3

Figures: 0

References: 39
Received: January 2014

Accepted: March 2014

Published: June 2014

\section{Corresponding author:}

Żaneta Szczepańska-Klunder

Gdansk University of Physical Education and Sport, Department of Pedagogy, Sociology and Philosophy

80-336 Gdansk, Poland, 1 Kazimierza Gorskiego St.

Phone: +4858 5547131

E-mail: zaneta.szczepanska-klunder@awfis.gda.pl 


\section{Introduction}

Keeping good health in a world full of stressors is possible, among other things, when one focuses on recognizing and reinforcing their personal traits, which gives a sense of coherence. This feature, being a central concept of salutogenesis, means a generalized, emotional and cognitive outlook on the world which enables an individual to notice and interpret phenomena around them as understandable, controllable and reasonable [1,2]. Such a view of this feature entails three components: comprehensibility, manageability and meaningfulness [2]. Comprehensibility expresses the cognitive aspect of a situation, which means perceiving the influx of information as organized, coherent and understandable.When considered in terms of health, comprehensibility can be said to allow for anticipation of certain health-related situations; when unexpected health-related circumstances occur, comprehensibility allows for understanding and organizing them, regardless of whether they are beneficial or detrimental to health. Manageability makes an individual resourceful when they are faced with life events; they feel they can cope with every difficulty. Manageability, as a cognitive and instrumental variable, is related to a sense of having remedial resources or measures available, which helps actively influence particular situations; it provides a belief that there is someone or something supportive around, in case such support is needed. From a health-oriented standpoint, remedial resources may encompass both one's own resources, such as knowledge about health, health beliefs and competencies, as well as other people's resources (family's, friends') which help us take health-oriented actions. The third component of the sense of coherence - meaningfulness - is related to a motivational and emotional attitude towards stimuli we experience. It is based on a belief that it is worth engaging in a given situation, seeking its meaning, and when a difficulty arises, meaningfulness helps perceive it as a challenge, not a threat. Meaningfulness entails that efforts made in order to keep or improve health are reasonable and worthwhile.

According to Antonovsky [2], the stronger the sense of coherence, the bigger the tendency to take pro-health action and avoid unhealthy behaviors. It was proved by Lindmark's et al. research [4], which indicates that a high sense of coherence is related to healthy dietary habits, while a low sense of coherence leads to less healthy dietary choices. Similarly, Posadzki et al. [5] confirm the beneficial role of the sense of coherence: an increase in the sense of coherence was accompanied by an increase in health-seeking behaviors. Healthy choices are supported mainly by a sense of reasonableness and resourcefulness, while a sense of coherence has the strongest impacton behaviors related to the psychological aspect of health $[6,7]$. The sense of coherence supports development and keeping good health, increases mental toughness and leads to a positive subjective health. Individuals with a strong sense of coherence enjoy better health and show a lower health problem rate compared to those who have a lower sense of coherence [10, 11]. Additionally, the sense of coherence plays a beneficial role in the subjective sense of well-being of youths [12] and is vital for keeping and promoting health choices amongst the elderly [13].

Schools and physical education classes play a key role in promoting health-seeking behaviors. By and large, it is the PE teacher who introduces students to the world of health culture $[15,16]$. However, teachers will successfully serve the role of a health promoter only if they themselves display a positive attitude towards their own health $[17,18]$.

As sense of coherence in analyzed in the context of broadly understood pro-health behaviors, it is worth asking whether the sense of coherence can be treated as an important indicator of PE teachers' health-oriented behaviors. Theoretical foundations of the sense of coherence state that variables influences health-related behaviors; therefore, it is justified to assume that there is a link between the sense of coherence and health-seeking behaviors related to physical activity, dietary choices, health practices, prophylactic actions, and positive attitude of PE teachers. Moreover, given the fact that the sense of coherence is related both to cognitive and motivational/emotional aspects of an individual, it is fair to assume that there is a correlation between the sense of coherence and its components, and self-assessment of health and fitness, as well as behaviors directed at improving health and fitness levels. 


\section{Material and Methods}

In order to determine the moderating role of sense of coherence in undertaking health-seeking behaviors, we examined a group of physical education teachers $(N=477)$, among whom were 235 women and 242 men, employed at various types of schools in the Pomeranian Voivodeship. The sample was chosen on a deliberately-random basis. The operate of sampling was an electronic list of public schools provided by the Superintendent of Schools Office in Gdansk; the schools rather than teachers were sampled. The participants' age ranged between 23 and 62 years $(M=40.05$; $S D=9.09$ ).

In order to assess the sense of coherence, the following method was used: The Sense of Coherence Questionnaire (SOC-29) by Antonovsky [19, 20] in the Polish adaptation by Koniarek, Dudek and Makowska [21]. The Sense of Coherence Questionnaire encompasses 29 questions, 11 of which relate to the subscale Sense of Comprehensibility, 10 relate to Sense of Manageability, and 8 relate to Sense of Meaningfulness. At this stage we must advise that the issue of factor structure in SOC-29 Questionnaire has not been settled in terms of the 3-factor construction of the sense of coherence [e.g. 20, 21, 22, 23, 24, 25]. In this study, Pasikowski's [22] standpoint was adopted, according to which it is advisable, and even necessary, to calculate not only the total score for the sense of coherence, but also for its components.

The level of health-seeking behaviors was measured with the Health Behavior Inventory $(\mathrm{HBI})$ by Juczynski [26]. $\mathrm{HBI}$ analyzes four categories of health-seeking behaviors: Proper Nutrition Habits, Prophylactic Behavior, Health Practices, and Positive Psychological Attitudes. We have also used a survey to collect the following variables: sex, hours spent on physical activity per week, the number of types of physical activity PE teachers takeup outside of work.

Self-reported levels of health and physical condition were determined with the Multidimensional Body-Self Relations Questionnaire by Cash [27]. The scale includes 69 questions divided into nine subscales. Two of these subscales, Fitness/Health Evaluation and Fitness/Health Orientation, were analyzed in the present study.

\section{Results}

At first, variables categorized by sex of PE teachers were analyzed (Table 1). A comparison of averages did not reveal dissimilarities between sexes in terms of the general sense of coherence, as well as its components. Analysis of PE teachers' health-seeking behaviors, however, exposed an average intensity of health-seeking behaviors, which confirms the general result of these behaviors (standard ten values: $M=5.96$; $S D=1.69$ ). Moreover, women displayed higher intensity of Proper Nutrition Habits, Prophylactic Behavior, Positive Psychological Attitudes and Health Practices than men.

Table 1. Comparison of averages for sense of coherence, health behavior, $M B S R Q$ in the examined group of PE teachers

\begin{tabular}{lccc}
\hline \multicolumn{1}{c}{ Scale } & Female & Male & Difference \\
& $M(S D)$ & $M(S D)$ & $t(p)$ \\
\hline Sense of Coherence & $139.20(19.13)$ & $138.95(20.13)$ & $0.13(0.891)$ \\
$\quad$ comprehensibility & $49.00(8.17)$ & $49.71(8.56)$ & $0.95(0.340)$ \\
manageability & $49.38(8.84)$ & $49.16(7.97)$ & $0.30(0.760)$ \\
$\quad$ meaningfulness & $40.82(7.00)$ & $40.07(7.14)$ & $1.17(0.241)$ \\
Health Behavior Inventory: & & & \\
$\quad$ proper nutritionhabits & $22.74(3.72)$ & $20.10(4.30)$ & $7.19(0.000)$ \\
$\quad$ prophylactic behavior & $22.10(4.00)$ & $20.20(4.30)$ & $5.05(0.000)$ \\
positive psychological attitudes & $22.77(3.34)$ & $21.85(3.73)$ & $2.81(0.005)$ \\
$\quad$ health practices & $20.50(3.55)$ & $19.64(3.77)$ & $2.48(0.014)$ \\
$\quad$ general intensity of health behavior & $88.08(11.00)$ & $81.80(12.74)$ & $5.77(0.000)$ \\
MBSRQ: & & & \\
$\quad$ Fitness/Health Evaluation & $42.75(5.44)$ & $43.14(5.52)$ & $0.76(0.445)$ \\
$\quad$ Fitness/Health Orientation & $52.02(5.70)$ & $50.53(5.33)$ & $3.00(0.003)$ \\
\hline
\end{tabular}


Women were involved in activities aimed at improving their health and fitness more than men. As far as health and fitness self-assessment is concerned, we did not note significant dissimilarities between sexes.

Considering variables related to physical activity, one can notice that women spend fewer hours on physical activity $\left(M_{\text {female }}=4.74 ; S D_{\text {female }}=3.26 ; M_{\text {male }}=5.93 ; S D_{\text {male }}=4.47 ; p=0.001\right)$ and prefer other forms of physical activity (Table 2). There were, however, no dissimilarities in terms of the number of physical activity types between PE teachers - on average, subjects took up one form of physical activity $(M=1.27 ; S D=0.73)$.

Table 2. Differences in terms of the preferred forms of physical activity among PE teachers

\begin{tabular}{lccc}
\hline PA form & Female & Male & $p$ \\
\hline Jogging & $26.0 \%$ & $23.31 \%$ & 0.353 \\
Aerobic & $24.25 \%$ & $0.41 \%$ & 0.000 \\
Basketball & $4.70 \%$ & $10.74 \%$ & 0.013 \\
Football & $0.42 \%$ & $24.40 \%$ & 0.000 \\
Volleyball & $17.90 \%$ & $16.53 \%$ & 0.698 \\
Weightlifting & $2.60 \%$ & $15.30 \%$ & 0.000 \\
Swimming & $25.53 \%$ & $16.53 \%$ & 0.016 \\
\hline
\end{tabular}

In order to estimate the impact of independent variables (Sense of Comprehensibility, Sense of Manageability, Sense of Meaningfulness, Fitness/Health Evaluation), dependent variables (Proper Nutrition Habits, Prophylactic Behavior, Positive Psychological Attitudes, Health Practices And Fitness/Health Orientation) were subjected to multiple regression analyses.

The most suitable regression model was for women $(F=35.85 ; p=0.000)$ - it explained a total of $38.41 \%$ of variation of Fitness/Health Orientation. Two out of four independent variables considered in this model had a significant impact on Fitness/Health Orientation: Sense of Manageability $(\beta=0.22 ; t=3.02 ; p=0.003)$ and Fitness/Health Evaluation $(\beta=0.55 ; t=10.14 ; p=$ $0.000)$. In the case of men with the dependent variable Fitness/Health Orientation, only Fitness/Health Evaluation had an effect $(\beta=0.43 ; t=7.01 ; p=0.000)$ - here, regression explained $21.24 \%$ of variation $(F=15.91 ; p=0.000)$.

An interesting model was yielded by regression with a dependent variable Positive Psychological Attitudes. For women, Positive Psychological Attitudes (20.00\% variation; $F=14.37$; $p=0.000)$ were influenced by Sense of Comprehensibility $(\beta=0.20 ; p=0.008)$ and Sense of Manageability $(\beta=0.27 ; p=0.001)$. As for men (14.15\% variation; $F=9.73, p=0.000)$, Positive Psychological Attitudes were influenced by Sense of Comprehensibility $(\beta=0.16 ; p=0.040)$ and Fitness/Health Evaluation $(\beta=0.18 ; p=0.004)$.

The correlation coefficient for the sense of coherence in SOC-29 scale with health-seeking behaviors in the $\mathrm{HBI}$ scale is presented in Table 3. It shows that more frequent engagement in health-seeking behavior is linked to subjects' Sense of Coherence, because the stronger it is, the more intensified subjects' practices related to Prophylactic Behavior, Positive Psychological Attitudes and Health Practices are. A similar correlation can be seen in terms of the sense of coherence components and health-seeking behavior. Nevertheless, there is no link between Proper Nutrition Habits/Health Practices and Sense of Meaningfulness. We did not note a relation between the sense of coherence and physical activity - and additionally for men, no link with Proper Nutrition Habits. 
Table 3. Correlation between the results of SOC-29, $H B I$ and $M B S R Q$ in the examined group of PE teachers

\begin{tabular}{lccccccc}
\hline \multicolumn{1}{c}{ Scale } & Sex & SOC-29 & COMP & MAN & MEAN & $\begin{array}{l}\text { Fitness/ } \\
\text { Health Evaluation }\end{array}$ \\
\hline PA: & $\mathrm{f}$ & 0.06 & 0.02 & 0.12 & 0.05 & 0.01 \\
Number of Hours & $\mathrm{m}$ & 0.06 & 0.04 & 0.06 & 0.06 & $0.26(0.000)$ \\
& $\mathrm{f}$ & $0.13(0.040)$ & $0.14(0.042)$ & 0.10 & 0.10 & -0.01 \\
Number of Forms & $\mathrm{m}$ & -0.03 & & -0.08 & -0.10 & 0.10 \\
HBI: & & & & & & & \\
Proper Nutrition Habits & $\mathrm{f}$ & $0.17(0.012)$ & $0.16(0.018)$ & $0.19(0.005)$ & 0.07 & $0.14(0.032)$ \\
& $\mathrm{m}$ & 0.07 & 0.10 & 0.03 & 0.05 & $0.13(0.044)$ \\
Prophylactic Behavior & $\mathrm{f}$ & $0.23(0.001)$ & $0.22(0.001)$ & $0.19(0.005)$ & $0.15(0.021)$ & $0.15(0.030)$ \\
& $\mathrm{m}$ & $0.20(0.002)$ & $0.16(0.012)$ & $0.17(0.008)$ & $0.19(0.004)$ & $0.21(0.001)$ \\
Positive Psychological Attitudes & $\mathrm{f}$ & $0.40(0.000)$ & $0.36(0.000)$ & $0.39(0.000)$ & $0.24(0.000)$ & $0.22(0.001)$ \\
& $\mathrm{m}$ & $0.33(0.000)$ & $0.30(0.000)$ & $0.30(0.000)$ & $0.23(0.000)$ & $0.27(0.000)$ \\
Health Practices & $\mathrm{f}$ & $0.16(0.016)$ & $0.18(0.007)$ & $0.17(0.013)$ & 0.04 & 0.11 \\
MBSRQ: & $\mathrm{m}$ & $0.20(0.002)$ & $0.20(0.002)$ & $0.19(0.004)$ & 0.11 & $0.15(0.020)$ \\
Fitness/Health Orientation & & & & & & \\
& $\mathrm{f}$ & $0.32(0.000)$ & $0.22(0.001)$ & $0.33(0.000)$ & $0.26(0.000)$ & $0.58(0.000)$ \\
& $\mathrm{m}$ & $0.19(0.003)$ & 0.12 & $0.17(0.007)$ & $0.20(0.002)$ & $0.45(0.000)$ \\
\hline
\end{tabular}

Note:r (p); f - female, m - male; COMP - sense of comprehensibility; MAN - sense of manageability; MEAN - sense of meaningfulness

A link between Fitness/Health Orientation and Sense of Coherence is observable both for men and women. Therefore, it can be stated that the stronger the sense of coherence amongst subjects, the more engaged they are in behaviors aimed at improving health and fitness. Additionally, Fitness/Health Evaluation is - statistically speaking - significantly related to health-seeking behaviors. What is more, the higher self-evaluation of health and fitness, the more intensified action of the subjects, aimed at improving health and fitness.

\section{Discussion}

Health-oriented behavior is - to a significant extent - dependent on what PE teachers think about the reality they live in, how they perceive it, what meaning they assign to certain events and how they evaluate them $[4,5,28]$. Relating it to the above presented results, it should be noted that individuals who displayed a higher sense of coherence had more health-oriented intensity ofProphylactic Behavior, Positive Psychological Attitudes and Health Practices. It should be noted that the strongest correlation with Sense of Coherence and its components was revealed for Positive Psychological Attitudes. It was also confirmed by means of a regression analysis - two elements of Sense of Coherence influence Positive Psychological Attitudes: comprehensibility and manageability. These results allow for assuming that Sense of Comprehensibility and Manageability may shape positive psychological attitudes, i.e. predispositions towards avoiding too intense emotions, stress and tension, which translates into keeping good health. It is convergent with data which indicate that an increased sense of coherence leads to better mental health and life satisfaction due to effective stress/anxiety/fear coping strategies [29, 30]. Moreover, the sense of coherence is believed to be a major prognostic factor for improving good mood [31]. As for women, the sense of coherence favors taking up action related to health dietary habits. It may result from higher awareness of well-balanced nutrition of women than men [32]. It should also be noted that women more often than men employ correct dietary habits in order to increase their physical appeal - not to enjoy health benefits [33, 34].

The revealed correlation between Sense of Coherence and Fitness/Health Orientation seems to be one of the most interesting findings. It proves that PE teachers engage in health/fitness-oriented activity because they feel that their efforts - despite difficulties - are worthwhile. It must be noted that this correlation was stronger for women than for men. It was further confirmed by a regression analysis, which showed that Sense of Manageability influences activities 
taken up by women to improve their health and fitness. This conclusion is also corroborated in other studies, which points to the fact that Sense of Manageability has agreaterimpact on health-oriented behaviors [6, 7]. On the one hand, it is convergent with other studies which indicate higher intensity of women's health-seeking behavior than men's [35, 36, 37]; on the other hand, however, it is visible that due to remedial resources, women are better than men at improving their own health and fitness.

It should be noted that the higher intensity of Fitness/Health Evaluation of PE teachers, the more importance they attach to Fitness/Health Orientation, Proper Nutrition Habits, Prophylactic Behavior, and Positive Psychological Attitudes. It may be assumed that it results from the role played by PE teachers in educating and promoting health amongst their students. A PE teacher who introduces students to the world of health culture should actively participate in it, setting a good example of positive health attitudes [14, 15].

It is surprising, however, that the sense of coherence does not favor physical activity, which is not convergent with Antonovsky's theory [2] and results of other studies[38, 39]. It must be noted, however, that in the presented research, physical activity was considered in the context of quantity, expressed as a number of hours spent on physical activity per week. Additionally, a different tool was used to measure physical activity, which may explain the differences in our results. Therefore, given the complexity and multi-aspect nature of health-seeking conditions, including physical activity, interpretation of the collected data shall be accompanied by certain caution in order to come to far-reaching conclusions.

Nonetheless, PE teachers spend little time weekly on physical activity.It is convergent with results of other studies in this field [36]. Perhaps barriers to participation in physical activity distorted the collected data, as the presented study did not control this variable. Furthermore, the study suggests that men spend more time on physical activity than women, which has been confirmed by other studies [39]. What is more, bigger time engagement of men in physical activity is linked to their health/fitness self-evaluation.

To sum up, it can be stated that the gathered data has partially confirmed initial assumptions. Lack of a link between the sense of coherence and physical activity can be explained in terms of complexity of conditions of health-seeking behavior.It requires taking into account other variables, such as the sense of locus of control and self-efficacy, life satisfaction, sense of worthiness and optimism. Nevertheless, the observed relation between the sense of coherence and health-seeking behavior confirmed our assumptions about the pro-health role of the sense of coherence in terms of health-oriented behavior. Determining levels of the sense of coherence and the intensity of health-seeking behavior may effectively influence the focus of health education amongst PE teachers. Given the above, interventive action taken in order to improve health-seeking behavior of $P E$ teachers should lead to an increased sense of coherence.

\section{Conclusion}

The study based on the examined group of PE teachers revealed results which indicate a positive role of the sense of coherence in taking up prophylactic behavior, positive psychological attitudes and health practices. Both men and women displayed an average indicator of healthseeking behaviors, which indicates a need for intervention in terms of health promotion and education among PE teachers. Changes in educating PE teachers may also be advisable.

\section{References}

1. Antonovsky A. Rozwiklanie tajemnicy zdrowia. Jak radzic sobie ze stresem i nie zachorowac? [Unraveling the mystery of health. How people manage stress and stay well]. Warszawa: Instytut Psychiatrii i Neurologii; 2005. Polish.

2. Antonovsky A. Poczucie koherencji jako determinant zdrowia [Sense of coherence as a determinant of health]. In: Heszen-Niejodek I, Sek I, editors. Psychologia zdrowia [Health Psychology]. Warszawa: PWN; 1997, 206-231. Polish.

3. Sęk H. Salutogeneza I funkcjonalne wlasciwosci poczucia koherencji [Salutogenesis and functional properties of the sense of coherence].]. In: Sek H, Pasikowski T, edistors. Zdrowie - Stres - Zasoby. O zna- 
czeniu poczucia koherencji dla zdrowia [Health-Stress-Resources. Sense of coherence and its importance to health]. Poznan: Wydawnictwo Fundacji Humaniora; 2001, 23-42. Polish.

4. Lindmark U, Stegmayr B, Nilsson B, Lindahl B, Johansson I. Food selection associated with sense of coherence in adults. Nutr J. 2005;4:9-16.

5. Posadzki P, Stockl A, Musonda P, Tsouroufli M. Amixed-method approach to sense of coherence, health behaviors, self-efficacy andoptimism: Towards the operationalization of positive health attitudes. Scand J Psychol. 2010; 51:246-252.

6. Sek H, Pasikowski T. editors. Zdrowie - Stres - Zasoby. O znaczeniu poczucia koherencji dla zdrowia [Health-Stress-Resources. Sense of coherence and its importance to health]. Poznan: Wydawnictwo Fundacji Humaniora; 2001. Polish.

7. Ziarko M. Zachowania zdrowotne mlodych doroslych - uwarunkowania psychologiczne [Health behavior of young adults - psychological conditions]. Poznan: Wydawnictwo Naukowe Bogucki; 2006. Polish.

8. Eriksson M, Lindstrom B. Antonovsky's sense of coherence scale and the relation with health: a systematic review. J Epidemiol Community Health. 2006;60:376-381.

9. Eriksson M, Lindstrom B. Antonovsky's sense of coherence scale and the relation with qualityof life: A systematic review. J Epidemiol Community Health. 2007;61:938-944.

10. Mikami A, Matsushita M, Adachi H, Suganuma N, Koyama A, Ichimi N, et. al.Sense of coherence, health problems, and presenteeism in Japaneseuniversity students. Asian J Psychiatr. 2013;6:369-372.

11. Togari T, Yamazaki Y, Takayama TS, Yamaki CK, Nakayama K.Follow-up study on the effects of sense of coherence on well-being after two years in Japanese university undergraduate students. Pers Individ Dif. 2008; 44(6):1335-1347.

12. Moksnes U, Lohre A, Espnes G.A. The association between sense of coherence and life satisfaction in adolescents. Qual Life Res. 2013;22:1331-1338.

13. Wiesmann U, Hannich HJ. A Salutogenic Analysis of Healthy Aging in Active Elderly Persons. Research on Aging. 2010;32:349-371.

14. Cale L, Harris J. School-based physical activity interventions: effectiveness, trends, issues, implications and recommendations for practice. Sport Educ Soc. 2006; 11(4):401-421.

15. Cale L, Harris J. 'Every child (of every size) matters' in physical education!Physical education's role in childhood obesity. Sport Educ Soc. 2013;18(4):433-453.

16. Green K. Mission impossible? Reflecting upon the relationship between physical education, youth sport and lifelong participation.Sport Educ Soc. 2012:1-19.

17. Patterson D, van der Mars H. Distant interactions and their effects on children's physical activity levels.Phys Educ Sport Pedagog. 2008;13(3):277-294.

18. Pino-Juste M, Gutierrez-Sanchez A, Alvarinas M. Trainee teachers' habits of healthy physical activity. J Hum Sport Exerc. 2013;8(2):458-468.

19. Antonovsky A. The Sense of Coherence: Development of a Research Instrument. Newsletter and Research Reports. WS. Schwartz Research Center for Behavioral Medicine. 1983;1:1-11.

20. Antonovsky A. The structure and properties of the sense of coherence scale. SocSci Med. 1993;36:725733.

21. Koniarek J, Dudek B, Makowska Z. Kwestionariusz Orientacji Zyciowej. Adaptacja The Sense of Coherence Questionnaire (SOC) A. Antonovsky`ego [Questionnaire of Life Orientation. Adaptation of Antonovsky'sSense of Coherence Questionnaire]. Przeglad Psychologiczny. 1993;36(4):491-502. Polish.

22. Pasikowski T. Kwestionariusz poczucia koherencji dla doroslych (SOC-29) [Sense of Coherence in Adults Questionnaire (SOC-29)]. In: Sek H, Pasikowski T, editors. Zdrowie-stres-zasoby. O znaczeniu poczucia koherencji dla zdrowia [Health-Stress-Resources. Sense of coherence and its importance to health]. Poznan: Wydawnictwo Fundacji Humaniora; 2001, 71-85. Polish.

23. Zwolinski M. Kontrowersje dotyczace struktury czynnikowej Kwestionariusza Orientacji Zyciowej (skali $\mathrm{SOC})$ A. Antonovsky'ego i ich rozstrzygnięcie w odniesieniu do proby uczniow ostatnich klas srednich szkoł zawodowych [Controversies Concerning Factor Structure Of Antonovsky's Orientation To Life Questionnaire (SocScale) And Their Solution For A Sample OE Vocational Secondary School Students]. Przeglad Psychologiczny. 2000;43(3):291-308. Polish.

24. Luszczynska-Cieslak A. Czym jest dla psychologa poczucie koherencji? [What it sense of coherence to a psychologist?]. Promocja Zdrowia. Nauki Spoleczne i Medycyna. 2001; 20:56-68. Polish.

25. Luszczynska-Cieslak A. Trudnosci dotyczace badan nad poczuciem koherencji [Difficulties in researching the sense of coherence]. In: Sek H, Pasikowski T, editors. Zdrowie-stres-zasoby. O znaczeniu poczucia koherencji dla zdrowia [Health-Stress-Resources, Sense of coherence and its importance to health]. Poznan: Wydawnictwo Fundacji Humaniora; 2001, 57-68. Polish.

26. Juczynski Z. Narzedzia pomiaru w promocji i psychologii zdrowia [Instruments for Measurement in HealthPromotion and Psychology]. Warszawa: Pracownia Testow Psychologicznych PTP; 2001. Polish. 
27. Cash TF. Users' manual for the Multidimensional Body Self Relations Questionnaire (3rd revision). Document available for purchase at the author's website at [www.body-images.com]; 2000.

28. Dolinska-Zygmunt G. Behawioralne wyznaczniki zdrowia - zachowania zdrowotne [Behavioral determinants of health - health behavior]. In: Dolinska-Zygmunt G, editor. Podstawy psychologii zdrowia [The basics of healthpsychology]. Wroclaw: Uniwersytet Wroclawski; 2001, 33-70. Polish.

29. Ying YW, Lee PA, Tsai JL. Predictors of depressive symptoms in Chinese American college students: parent and peer attachment, college challenges and sense of coherence. Am J Orthopsychiatry. 2007;77(2):316-323.

30. Surtees PG, Wainwright NW, Khaw KT. Resilience,misfortune, and mortality: evidence that sense of coherence is a markerof social stress adaptive capacity. J Psycho Res. 2006;61(2):221-227.

31. Oztekin C, Tezer E. The role of sense of coherence and physical activity in positive and negative affect of Turkish adolescents. Adolescence. 2009;44(174):421-432.

32. Duvigneaud N, Wijndaele K, Matton L, et al. Dietary factors associated with obesity indicators and level of sports participation in Flemish adults: a cross-sectional study. Nutr J. 2007;6:26-37.

33. Pearson ES, Hall CR. Examining body image and its relationship to exercise motivation: An 18-week cardiovascular program for female initiates with overweight and obesity. Balt $\mathrm{J}$ Health Phys Act. 2013;5(2):121-131.

34. Lipowski M, Bulinski L, Krawczynski M. Physical activities among other types of health-related behaviour in people losing weight. Med Sci Monit. 2009;15(8):423-428.

35. Wang WC, Worsley A, Hunter W. Similar but different. Health behavior pathways differ between men and women. Appetite. 2012;58(2):760-766.

36. Lipowski M, Szczepanska-Klunder Z. Zachowania zdrowotne nauczycieli wychowania fizycznego [Health-seeking behaviors of physical education teachers]. In: Jastrzebski Z, editor. Teoria wychowania fizycznego i sportu [Theory of PhysicalEducation and Sport]. Lodz: Wyzsza Szkoła Sportowa, 9-26. Polish.

37. Hankonen N, Absetz P, Ghisletta P, Renner B, Uutela A. Gender differences in social cognitive determinants of exercise adoption. Psychol Health. 2010;25(1):55-69.

38. Ahola AJ, Mikkila V, Saraheimo M, et al. Sense of coherence, food selection and leisure time physical activity in type 1 diabetes. Scand J Public Health. 2012;40(7):621-628.

39. Endo S, Kanou H, Oishi K. Sports activities and sense of coherence (SOC) among college students. Int J Sport Health Sci. 2012;10:1-11. 